\title{
Pengaruh Penerapan Media Teka-teki Silang Diakhir Pembelajaran Model Discovery terhadap Hasil Belajar Peserta Didik Kelas XI MIA SMA Kartika XX-1 Makassar (Studi pada Materi Pokok Larutan Penyangga)
}

\author{
Nurfitri, Muhammad Syahrir*, Muhammad Anwar \\ Jurusan Kimia, FMIPA Universitas Negeri Makasar, Indonesia \\ *syahrir_gassa@yahoo.com
}

\begin{abstract}
Abstrak
Penelitian ini adalah penelitian eksperimen semu (quasi experimental) yang bertujuan untuk mengetahui pengaruh penggunaan media teka-teki silang (TTS) diakhir pembelajaran model discovery terhadap hasil belajar peserta didik kelas XI MIA SMA Kartika XX-1 Makassar. Desain penelitian adalah pretest-posttest control group design. Populasi penelitian ini adalah peserta didik kelas XI MIA SMA Kartika XX-1 Makassar yang terdiri dari 7 kelas. Penentuan sampel dilakukan secara random. Variabel bebas adalah media TTS diakhir model pembelajaran discovery dan variabel terikatnya yaitu hasil belajar tanpa menggunakan media TTS diakhir pembelajaran menggunakan discovery learning tanpa TTS. Hasil analisis data baik secara deskriptif menunjukkan rata-rata hasil belajar dalam bentuk $N$-Gain peserta didik kelompok eksperimen dan kelompok kontrol berturut-turut adalah 0.649 dan 0.527 termasuk (kategori sedang). Sedangkan analisis statistik inferensial diperoleh hasil pengujian hipotesis terhadap hasil belajar menggunakan uji- $t$ diperoleh $t_{\text {hitung }}=2,652>t_{\text {tabel }}=1,67$. Berdasarkan hasil analisis data tersebut dapat disimpulkan bahwa terdapat pengaruh positif penggunaan media TTS pada akhir model pembelajaran discovery terhadap hasil belajar peserta didik kelas XI MIA SMA Kartika XX-1 Makassar pada materi pokok larutan penyangga.
\end{abstract}

Kata kunci: discovery, hasil belajar, media.

\section{Identitas Artikel:}

Nurfitri, N., Syahrir, M., \& Anwar, M. (2021). Pengaruh Penerapan Media Teka-teki Silang Diakhir Pembelajaran Model Discovery terhadap Hasil Belajar Peserta Didik Kelas XI MIA SMA Kartika XX-1 Makassar (Studi pada Materi Pokok Larutan Penyangga). Jurnal Ilmu Pendidikan (JIP) STKIP Kusuma Negara, 13(1), 76-83.

\section{PENDAHULUAN}

Pendidikan adalah usaha sadar, terencana dan sistematis dalam mengembangkan dan meningkatkan kualitas serta potensi yang dimiliki oleh SDM. Persiapkan generasi muda bangsa dalam menghadapi kehidupan dimasa depan dimana pendidikan menjadi hal yang sangat penting. Keberhasilan dari pendidikan sangat dipengaruhi oleh proses pembelajaran yang dilakukan.

Kegiatan menyampaikan pesan dapat dikatakan sebagai pembelajaran yang terdiri dari: pengetahuan, keterampilan, dan sikap dari guru kepada peserta didik. Guru dan peserta didik sendiri merupakan salah satu faktor penentu keberhasilan proses pembelajaran. Guru mempunyai beberapa peranan dalam proses pembelajaran yaitu sebagai informator, motivator, fasilitator, pembimbing, 
korektor, inspirator, organisator, demonstrator, pengelola kelas, mediator, supervisor, dan evaluator (Noor, 2013). Selain guru berperan dalam bidang akademik, guru juga berperan mendidik karakter siswa. Untuk itu guru perlu mendesain proses belajar mengajar menjadi menyenangkan dan membuat siswa menjadi berperan aktif dalam proses pembelajaran. Jika hal ini terjadi maka tujuan pembelajaran dan pendidikan nasional dapat tercapai dengan mudah.

Hasil belajar pada materi larutan penyangga sesuai hasil di SMA Kartika XX1 bahwa persentase jumlah peserta didik yang tuntas pada ulangan harian dengan nilai KKM (Kriteria Ketuntasan Minimal) 76 adalah sekitar 50-60\%, sehingga berdasarkan hal tersebut maka belum memenuhi kriteria ketuntasan kelas yang telah ditetapkan yaitu $78 \%$. Salah satu faktor yang menyebabkan hal tersebut yaitu media pembelajaran yang diterapkan selama ini tidak akan pernah cocok karena karakteristik berbeda-beda dari masing-masing peserta didik di SMA Kartika XX-1 ketika menghadapi pelajaran kimia khususnya materi larutan penyangga. Pada pokok bahasan ini banyak berkaitan mengenai konsep serta aplikasinya.

Proses pembelajaran belum terlaksana efektif karena masih rendahnya hasil belajar peserta didik saat proses pembelajaran. Mereka selalu beranggapan bahwa kimia sulit untuk dipahami. Selain tentang pemahaman rumus-rumus kimia, peserta didik juga harus paham dengan konsep-konsep kimia itu sendiri. Serta masih banyak peserta didik kurang teliti pada saat mengindentifikasi masalah yang diberikan oleh guru, karena kebiasaannya yang cenderung menerima materi tanpa memahaminya terlebih dahulu.

Guru harus mampu berbeperan aktif agar peserta didik dapat mengatasi masalah dalam proses pembelajaran yaitu dengan menggunakan model pembelajaran yang dapat menyebabkan peserta didik berperan aktif dalam proses pembelajaran. Selain berperan aktif, yang perlu diperhatikan juga adalah bagaimana pada proses pembelajaran peserta didik merasa nyaman dan tidak tertekan, sehingga pembelajaran yang efektif dan efisien dapat terwujud. Salah satu model pembelajaran yang sesuai dan dapat digunakan dalam mengatasi masalah dalam pembelajaran kimia adalah model discovery learning.

Discovery learning merupakan model pembelajaran yang membuat peserta didik terlibat secara aktif menggunakan proses mentalnya untuk menemukan berbagai konsep dan prinsip materi yang sedang dipelajari. Bahan ajar yang disajikan dalam bentuk pertanyaan atau permasalahan yang harus diselesaikan. Jadi peserta didik memperoleh pengetahuan yang berasal dari penemuan sendiri (Rusman, 2013; Zulfajri \& Amelia, 2016). Kegiatan peserta didik dalam pelaksanaan model ini masih kurang begitu aktif sehingga diperlukan suatu media tertentu dalam membuat peserta didik semakin kreatif dan inovatif dalam melakukan pemecahan masalah. Untuk meningkatkan kreatifitas dan inovasi peserta didik dalam proses pembelajaran menggunakan model discovery learning tersebut maka digunakan salah satu media yaitu TTS.

Upaya yang dilakukan dalam meningkatkan hasil belajar peserta didik yaitu penggunaan media TTS dan strategi tertentu (Djamarah \& Zain, 2006; Abimanyu \& La Sulo, 2008). TTS merupakan strategi peninjauan kembali yang dapat membantu peserta didik mengingat tentang materi yang telah disampaikan oleh guru. Menerapkan strategi ini dapat melibatkan kemampuan peserta didik untuk menjawab suatu masalah berupa TTS. TTS ini suatu permainan dimana peserta 
didik harus mengisi ruang-ruang kosong (berbentuk kotak putih) dengan huruf atau angka berdasarkan petunjuk yang diberikan. TTS dapat membuat peserta didik lebih termotivasi dalam belajar dan membuat proses pembelajaran lebih menarik (Rakhmadhani, Yamtinah \& Utomo, 2013; Uno \& Muhammad, 2011).

Penggunaan media TTS pada model discovery learning telah digunakan oleh (Yumila, Megasyani \& Yanti, 2017) pada hasil belajar fisika peserta didik, dengan menerapkan TTS dalam pembelajaran discovery learning lebih baik daripada hasil belajar fisika peserta didik yang hanya menggunakan pembelajaran discovery learning pada kelas XI MIPA SMAN 14 Padang. Berdasarkan Hasil penelitian (Zulfajri \& Amelia, 2016) pada materi kimia sistem koloid di kelas XI MIPA MAN Indrapuri Banda Aceh, diperoleh hasil bahwa penerapan model discovery learning dengan media TTS sangat disukai oleh peserta didik dan layak digunakan dalam proses pembelajaran sehingga mampu meningkatkan hasil belajar peserta didik. Mengingat bahwa teka teki silang tersebut mengarah kepada ingatan peserta didik sehingga dalam mempelajari materi larutan penyangga selama proses di akhir pembelajaran discovery mereka memerlukan pengetahuan konsep dan teori-teori praktis yang perlu dikuasai peserta didik, sehingga untuk melihat sejauh mana ingatan mereka sambil memanfaatkan salah satu media teka teki silang yang dapat menambah ketertarikan peserta didik dalam mempelajari materi pelajaran. Berdasarkan uraian di atas yang menjadi salah satu faktor pendukung penulis menggunakan media TTS diakhir pembelajaran discovery dalam penelitian.

\section{METODE PENELITIAN}

Penelitian ini merupakan penelitian eksperimen semu (Quasi Eksperiment). Variabel dalam penelitian ini terdiri dari variabel bebas dan variabel terikat (Siregar, 2016). Variabel bebas yaitu, hasil belajar menggunakan model discovery learning dengan menggunakan media TTS di akhir pembelajaran. Sedangkan, variabel terikat yaitu hasil belajar menggunakan model discovery learning di akhir pembelajaran tanpa media TTS.

Instrumen dalam penelitian ini berupa tes objektif dalam bentuk pilihan ganda sebanyak 20 butir soal dengan lima pilihan jawaban. Soal yang digunakan dipilih dari dua puluh lima soal yang telah melalui proses validasi isi oleh validator dan validasi item.

Hasil belajar peserta didik yang diperoleh dalam bentuk skor dikonversi ke bentuk nilai dengan rumus:

$$
\text { Nilai }=\frac{\text { Skor yang diperoleh peserta didik }}{\text { Skor maksimum }} \times 100 \ldots(\text { Sudjana }, 2011)
$$

Tabel 1. Kriteria Ketuntasan Belajar

\begin{tabular}{cc}
\hline Nilai & Kategori \\
\hline$\geq 78$ & Tuntas \\
$<78$ & Tidak tuntas \\
\hline
\end{tabular}

Sumber: SMA Kartika XX-1 Makassar 
Adapun hipotesis dari penelitian ini yaitu "media TTS diakhir pembelajaran discovery ada pengaruh positif terhadap hasil belajar kimia peserta didik kelas XI MIA SMA Kartika XX-1 Makassar pada materi pokok larutan penyangga" seperti pada Tabel 1.

\section{HASIL PENELITIAN}

Analisis Statistik Deskriptif

Analisis statistik deskriptif bertujuan untuk memberikan gambaran umum mengenai karakteristik pencapaian hasil belajar peserta didik pada kelas eksperimen dan kelas kontrol (Siregar, 2016).

Tabel 2. Nilai Statistik Hasil Belajar Peserta Didik

Kelompok Eksperimen dan Kelompok Kontrol

\begin{tabular}{lcccc}
\hline \multirow{2}{*}{ Statistik Deskriptif } & \multicolumn{3}{c}{ Nilai Statistik Kelompok } \\
\cline { 2 - 5 } & \multicolumn{2}{c}{ Eksperimen } & \multicolumn{2}{c}{ Kontrol } \\
\cline { 2 - 5 } & Pretes & Postes & Pretes & Postes \\
\hline Ukuran Sampel & 31 & 31 & 33 & 33 \\
Nilai Terendah & 55 & 50 & 10 & 45 \\
Nilai Tertinggi & 55 & 95 & 50 & 90 \\
Nilai rata-rata & 28,98 & 76,20 & 25,93 & 66,19 \\
Median & 27,10 & 80,54 & 11,88 & 92,5 \\
Modus & 25,82 & 80,86 & 16,29 & 84,66 \\
Standar Deviasi & 14,29 & 11,70 & 10,22 & 13,96 \\
\hline
\end{tabular}

Tabel 2 menunjukkan bahwa nilai rata-rata yang diperoleh kelompok eksperimen lebih tinggi dibandingkan kelompok kontrol.

\section{Analisis Statistik Inferensial}

Uji normalitas dilakukan dengan tujuan untuk mengetahui normal atau tidaknya populasi yang digunakan (Sudjana, 2002). Uji normalitas menggunakan statistik uji chi-kuadrat $\left(\chi^{2}\right)$, data dikatakan normal apabila $\chi^{2}$ hitung $<\chi^{2}$ tabel. Dari hasil perhitungan analisis statistik inferensial untuk data hasil belajar peserta didik pada kelas eksperimen diperoleh $\chi^{2}$ hitung $=5,0000$ dan kelas kontrol diperoleh 5,5366. Nilai untuk $\chi^{2}$ tabel pada taraf kepercayaan $(\alpha)=0,05$ dan derajat kebebasan $(d k)=$ 3 diperoleh nilai $\chi_{\text {tabel }}^{2}=7,815$. Pada kelas eksperimen $\chi^{2}$ hitung $<\chi_{\text {tabel }}^{2}$ dan kelas kontrol $\chi^{2}$ hitung $<\chi^{2}$ tabel maka disimpulkan bahwa hasil belajar pada kelas eksperimen dan kelas kontrol berdistribusi normal.

Uji homogenitas dilakukan untuk mengetahui apakah data dari kedua kelas bersifat homogen atau tidak. Kriteria pengujian homogenitas yaitu $F_{\text {hitung }}<F_{\text {tabel }}$. Berdasarkan hasil uji homogenitas untuk data hasil belajar dengan menggunakan varians dari kelas kontrol sebagai varians terbesar dan varians dari kelas eksperimen sebagai varians terkecil, maka diperoleh data $F_{\text {hitung }}=1,26$. Nilai $F_{\text {tabel, }}$ pada taraf kepercayaan 0,05 sebesar 1,81 . Karena nilai $F_{\text {hitung }}<F_{\text {tabel }}$ maka dapat disimpulkan bahwa varians kelas eksperimen dan kelas kontrol berasal dari populasi yang homogen.

Hasil uji prasyarat untuk hasil belajar, data berdistribusi normal dan berasal dari varians yang homogen, maka dilanjutkan dengan uji hipotesis. Pada uji 
hipotesis digunakan uji- $t$ satu pihak. Uji- $t$ dilakukan pada masing-masing kelas eksperimen dan kelas kontrol.

Hasil pengujian hipotesis nilai $\mathrm{N}$-Gain dengan uji- $t$ kelompok eksperimen dan kelompok kontrol diperoleh data sebagaimana terdapat dalam Tabel 3.

Tabel 3. Hasil Pengujian Hipotesis Nilai N-Gain

\begin{tabular}{lcccccc}
\hline \multicolumn{1}{c}{ Kelas } & Jumlah & $d k$ & Rata-rata $N$-Gain & $t_{\text {hitung }}$ & $t_{\text {tabel }}$ & Keputusan \\
\hline Eksperimen & 31 & \multirow{2}{*}{62} & 0,649 & 2,652 & 1,67 & $\mathrm{H}_{1}$ diterima \\
Kontrol & 31 & & 0,527 & & & \\
\hline
\end{tabular}

Berdasarkan Tabel 3 di atas diperoleh nilai $t_{\text {hitung }}=2,652$ dan nilai $t_{\text {tabel }}$ pada taraf kepercayaan $(\alpha)=0,05$ dan derajat kebebasan $(d k)=62$ yaitu 1,67. Dari analisis uji hipotesis ini diperoleh $t_{\text {hitung }}>t_{\text {tabel }}$, sehingga $\mathrm{H}_{1}$ diterima dan $\mathrm{H}_{0}$ ditolak. Ini berarti bahwa terdapat pengaruh penggunaan media berbasis TTS di akhir model pembelajaran discovery terhadap hasil belajar peserta didik kelas XI MIA SMA Kartika XX-1 Makassar pada materi pokok larutan penyangga.

\section{PEMBAHASAN}

Penelitian ini dilakukan untuk mengetahui pengaruh penggunaan media TTS diakhir pembelajaran model discovery terhadap hasil belajar peserta didik. Kedua kelas diberikan perlakuan yang sama. Hanya saja pada kelas eksperimen diberikan media TTS diakhir pembelajaran discovery learning sebagai pengganti evaluasi pada umumnya, sedangkan pada kelas kontrol diberikan model pembelajaran discovery learning tanpa media TTS diakhir pembelajaran (Anita, 2010, Dananjaya, 2010; Darmadi, 2017). Media TTS diakhir model pembelajaran discovery learning ini diharapkan mampu meningkatkan pemahaman peserta didik terhadap materi larutan penyangga.

Setelah melakukan proses pembelajaran selama empat kali pertemuan, dilakukan tes hasil belajar atau posttest. Hasil yang diperoleh pada posttest dengan nilai terendah dan tertinggi untuk posttest pada kelas eksperimen yaitu 50 dan 95 lebih besar dibandingkan nilai terendah dan tertinggi untuk posttest pada kelas kontrol yaitu 45 dan 90. Nilai rata-rata posttest kelompok eksperimen dan kelompok kontrol yaitu 76,20 dan 66,19. Adapun nilai standar deviasi untuk kelompok eksperimen pada saat pretest dan posttest yaitu 14,29 dan 11,70 sedangkan nilai standar deviasi untuk kelompok kontrol pada saat pretest dan posttest yaitu 10,22 dan 13,96. Perbedaan hasil belajar juga terlihat dari perolehan $N$-Gain pada kelompok eksperimen kategori tinggi sebesar $61,29 \%$ dan pada kelompok kontrol kategori tinggi sebesar 30,30\%.

Tabel 1 menunjukkan bahwa penggunaan model pembelajaran dengan media TTS diakhir pembelajaran discovery memberikan hasil belajar yang lebih baik. Hal ini membuktikan bahwa ada peningkatan pemahaman peserta didik terhadap materi pembelajaran yang disajikan, karena selama proses pembelajaran berlangsung peserta didik tertarik dengan media evaluasi yang digunakan sehingga peserta didik antusias dan semangat dalam proses pembelajaran sehingga mereka aktif dalam proses pembelajaran di kelas (Djamarah \& Zain, 2006). 
Tabel 2 menunjukkan bahwa ketuntasan kelompok eksperimen lebih besar dibandingkan kelompok kontrol yaitu 58,06 \% dan 39,39\%. Ketuntasan kelompok eksperimen cukup baik, hal ini didukung dengan persentase jumlah peserta didik yang tuntas relatif tinggi daripada peserta didik yang tidak tuntas. Selain itu, berdasarkan ketuntasan indikator pada kedua tersebut, kelompok eksperimen memiliki ketuntasan yang lebih tinggi dibandingkan dengan kelompok kontrol. Hal ini sejalan dengan hasil penelitian (Yumila et al., 2017) pada hasil belajar fisika peserta didik, dengan menerapkan TTS dalam pembelajaran discovery learning lebih baik dari pada hasil belajar fisika peserta didik yang hanya menggunakan pembelajaran discovery learning pada kelas XI MIPA SMAN 14 Padang.

Hasil belajar yang berbeda pada kedua kelas juga didukung oleh hasil perhitungan $N$-Gain yang diperoleh, dimana kelompok eksperimen memberikan nilai rata-rata $N$-Gain yaitu 0,649 dengan kelompok kontrol yaitu 0,527 . Hal ini membuktikan bahwa dalam proses pembelajaran yang berlangsung pada kelompok eksperimen lebih tinggi dibandingkan kelompok kontrol.

Persentase pencapaian tiap indikator menunjukan bahwa kelompok eksperimen lebih tinggi daripada kelompok kontrol, hal ini diketahui dari sepuluh indikator yang ada, diantaranya kelompok eksperimen memperoleh hasil lebih tinggi dibandingkan dengan kelompok kontrol. Sedangkan kelompok kontrol hanya unggul dua indikator, yaitu indikator satu dan tiga. Presentase ketuntasan pada kelompok eksperimen terdapat 1 indikator yang mencapai ketuntasan yaitu indikator 7 dengan presentasi ketuntasan yang cukup tinggi dibandingkan dengan kelompok kontrol, sedangkan persentase ketercapaian indikator pada kelompok kontrol tidak terdapat indikator yang mencapai ketuntasan. Dapat dilihat pada indikator 1 hasil pada kedua, kelompok kontrol 48,48\% lebih besar dibandingkan kelompok eksperimen 41,93\% dan indikator 3 kelompok kontrol 39,39\% lebih besar dibandingkan kelompok eksperimen $32,25 \%$ hal ini disebabkan dari penggunaan media TTS pada kelompok eksperimen sedangkan kelompok kontrol tidak menggunakan TTS.

Hasil uji prasyarat analisis statistik inferensial diperoleh data hasil belajar kedua kelompok terdistribusi normal dimana $\chi^{2}$ hitung $<\chi^{2}$ tabel, untuk kelompok eksperimen nilai $\chi^{2}$ hitung yaitu 5,000 dan nilai $\chi^{2}$ tabel yaitu 7.81 dan untuk kelas kontrol nilai $\chi^{2}$ hitung yaitu 5,5366 dan nilai $\chi^{2}$ tabel yaitu 7,81. Sedangkan untuk homogenitas dengan menggunakan uji- $F$ diperoleh data hasil belajar kedua kelompok adalah homogen dengan kriteria pengujian, jika $F_{\text {hitung }}<F_{\text {tabel }}$ maka varians bersifat homogen. Data yang diperoleh adalah nilai $F_{\text {tabel }}(0.05)(30 / 32)$ sebesar 1,81 dan $F_{\text {hitung }}$ sebesar 1,26. Oleh karena telah memenuhi asumsi maka dapat dilakukan pengujian hipotesis pada data tersebut. Untuk mengetahui apakah hipotesis yang diajukan diterima atau tidak maka dilakukan uji-t yang hasilnya $t_{\text {hitung }}(2,652)>t_{\text {tabel }}(1,67)$, sehingga $\mathrm{H}_{1}$ diterima dan $\mathrm{H}_{0}$ ditolak. Ini berarti ada pengaruh penggunaan media berbasis TTS diakhir model pembelajaran discovery terhadap hasil belajar peserta didik kelas XI MIA SMA Kartika XX-1 Makassar pada materi pokok larutan penyangga.

Hal ini di dukung oleh Zaini (2008) menyatakan bahwa teka-teki dapat digunakan sebagai pembelajaran yang baik dan menyenangkan tanpa kehilangan esensi belajar yang sedang berlangsung, bahkan pembelajaran dengan ini dapat melibatkan partisipasi peserta didik secara aktif sejak awal. Hasil penelitian 
(Zulfajri \& Amelia, 2016) pada materi kimia sistem koloid di kelas XI MIPA MAN Indrapuri Banda Aceh, diperoleh hasil bahwa penerapan model discovery learning dengan media TTS sangat disukai oleh peserta didik dan layak digunakan dalam proses pembelajaran sehingga mampu meningkatkan hasil belajar peserta didik.

TTS merupakan metode dimana peserta didik harus mengisi ruang-ruang kosong (berbentuk kotak putih) dengan huruf atau angka berdasarkan petunjuk yang telah diberikan sehingga membentuk kata yang dapat dibaca, baik secara vertikal maupun horizontal (Yumila et al., 2017; Rakhmadhani et al., 2013; Widiasworo, 2017; Zulfajri \& Amelia, 2016). Metode TTS ini dapat membuat peserta didik lebih termotivasi dalam proses pembelajaran sehingga dapat lebih menarik.

\section{SIMPULAN}

Dari hasil analisis data dan pembahasan maka dapat disimpulkan bahwa terdapat pengaruh penerapan media TTS diakhir pembelajaran model discovery terhadap hasil belajar peserta didik kelas XI MIA SMA Kartika XX-1 Makassar pada materi pokok larutan penyangga.

\section{UCAPAN TERIMA KASIH}

Penulis mengucapkan terima kasih kepada pihak Pimpinan, Dosen Jurusan Kimia FMIPA Universitas Negeri Makasar dan Kepala SMA Kartika XX-1 Makassar serta semua pihak yang terlibat sehingga penelitian ini dapat terselesaikan dengan baik.

\section{DAFTAR PUSTAKA}

Abimanyu, S., \& La Sulo, S. L. (2008). Strategi Pembelajaran. Jakarta: DEPDIKNAS.

Anita, S. (2010). Media Pembelajaran. Surakarta: Yuma Presindo

Dananjaya, U. (2010). Media Pembelajaran Aktif. Bandung: Nuansa Cendekia.

Darmadi, H. (2017). Pengembangan Model dan Metode Pembelajaran dalam Dinamika Belajar Siswa. Yogyakarta: Deepublish.

Djamarah, S. B., \& Zain, A. (2006). Strategi Belajar Mengajar. Jakarta: Rineka Cipta.

Noor, A. F. (2013). Modul Belajar dan Pembelajaran. Palangkaraya: Universitas Muhammadyah Palangkaraya.

Rakhmadhani, N., Yamtinah, S., \& Utomo, S. B. (2013). Pengaruh Penggunaan Metode Teams Games Tournaments Berbantuan Media Teka - Teki Silang dan Ular Tangga dengan Motivasi Belajar terhadap Prestasi Siswa Pada Materi Koloid Kelas XI SMA Negeri 1 Simo Tahun Pelajaran 2011/2012. Jurnal Pendidikan Kimia, 2 (4), 190-197.

Rusman. (2013). Model-Model Pembelajaran: Mengembangkan Profesionalisme Guru (2nd ed.). Depok: Raja Grafindo Press.

Siregar, S. (2016). Statistika deskriptif untuk penelitian. Depok: Raja Grafindo Persada. 
Sudjana. (2002). Metode Statistika. Bandung: Tarsito.

Sudjana, N. (2011). Penilaian Hasil Proses Belajar Mengajar. Bandung: Remaja Rosdakarya.

Uno, H. B., \& Muhammad, N. (2011). Belajar dengan Pendekatan PAILKEM: Pembelajaran, Aktif, Inovatif, Lingkungan, Kreatif, Menarik. Jakarta: Bumi Aksara.

Widiasworo, E. (2017). Strategi dan Metode Mengajar Siswa di Luar Kelas (Outdoor Learning): Secara Aktif, Kreatif, Inspiratif, dan Komunikatif. Yogyakarta: Ar-Ruzz Media.

Yumila, R., Megasyani, A., \& Yanti, I. R. (2017). Pengaruh Penerapan Teka-teki silang Dalam Pembelajaran Discovery Learning Terhadap Hasil Belajar Fisika Siswa Kelas XI MIPA SMAN 14 Padang. Jurnal Riset Fisika Edukasi dan Sains, 3 75-86. https://doi.org/https://doi.org/10.22202/jrfes.2017.v3i2.2501

Zaini, H. (2008). Strategi Pembelajaran Aktif. Yogyakarta: Pustaka Insan Madani. Zulfajri, M., \& Amelia, R. (2016). Pengaruh Model Discovery learning Dengan Media Teka-Teki Silang Terhadap Peningkatan Hasil Belajar Siswa pada Materi Sistem Koloid. Jurnal Edukasi Kimia, 1(1), 12-18. 